\title{
Adolf Berle During the New Deal: The Brain Truster as an Intellectual Jobber
}

\author{
Robert B. Thompson*
}

\section{INTRODUCTION}

Adolf Berle's ideas have attained a remarkable longevity in corporate law with an influence exceeding that of any other twentieth century law professor. ${ }^{1}$ Participants in the now ten Berle symposia often have framed the discussion of his career as an intellectual history, usually built around the powerful transformative effect of The Modern Corporation and Private Property (MCPP). ${ }^{2}$ Yet this approach is insufficient to explain large parts of Berle's professional career, including what Berle did during the twelve years of the Roosevelt Administration that immediately followed MCPP. This Article offers an alternative focus that better accounts for the career of an intellectual jobber, as Berle described himself. Intellectual history is still relevant-how could it not be when ideas were Berle's stock in trade-but political history is at the forefront of this account, with particular attention to the interaction of Berle's personal traits in this historical context, particularly his inclination to focus on one-off settings into which he could parachute and quickly exit.

This opening section provides introductory observations as to: Berle's biography before, during, and after the New Deal; the evolution of his writing during those periods; and the personal traits that shaped his entire professional life. Parts I and II focus on Berle during the Roosevelt Administration, the first five years based in New York City (but still an important participant in the President's circle) and the last seven at the

* Peter P. Weidenbruch Jr. Professor of Business Law, Georgetown University. I am grateful to Bill Bratton, Daniel Ernst and Brad Snyder for sharing comments and sources about the New Deal and Berle and to Elizabeth Pollman for linking Berle the corporate academic to his writing on broader policy issues. Jeremy Goldstein and Sherry Yu provided helpful research on this project.

1. Some have gone further, such as the editors of the LETTERS OF LOUIS D. BRANDEIS who described Berle as "one of the most influential public policy intellectuals of the Twentieth Century." See 4 LetTers of Louis D. BRANDEIS 36-37 (Melvin I. Urofsky \& David W. Levy eds., 1975) [hereinafter BRANDEIS LETTERS].

2. See generally Adolf A. Berle, JR. \& Gardiner C. Means, The Modern Corporation AND PRIVATE ProperTy (N.Y., Harcourt, Brace \& World, rev. ed. 1968) (1932) [hereinafter MCPP]. 
State Department (and immediately adjacent to the White House). Part III is a briefer treatment of his time after the New Deal. Each part develops an observation visible in each setting-Berle as a brain truster, intellectual jobber, and public intellectual. He was able to command most any topic on short notice and articulate a vision of a changed role for government in the economy, but less able to effectively implement policies reflecting those ideas. Part II.B takes a deep dive into the preparations of the American government during the time that Berle was at the State Department for a post-war international economic order, particularly planning for new international institutions in trade, monetary policy, and assembling global capital. This examination is valuable, independent of any discussion of Berle, for framing Brexit, Trump, and key current disagreements on the global economic stage, but it also helps understand Berle and his role during the New Deal.

Berle was raised mostly in the Boston area, recognized as a child prodigy before entering Harvard College at age fourteen, followed by Harvard Law and a job at the Brandeis firm. World War I intervened, providing experiences that stimulated his life-long interests in Latin America and diplomacy, but even more significantly led him to turn away from his Boston and Harvard roots and make his way in New York City. There, his public commentary on foreign affairs, involvement in Native American issues in the West, and living in the Henry Street settlement gave way to a determined focus to reframe corporate law for a new era. ${ }^{3}$ In 1932, his book with Gardiner Means, MCPP, set out the separation of ownership and control in the American corporation that shaped federal regulatory policy in corporate law for the remainder of the century. ${ }^{4} \mathrm{~A}$ contemporaneous exchange on the pages of the Harvard Law Review with Merrick Dodd framed a debate on the purpose of the corporation-for the benefit of shareholders or other stakeholders-that still anchors contemporary discussions of that topic. ${ }^{5}$ During that same year, as a

3. Jordan Schwarz's biography of Berle very effectively covers this and other parts of Berle's life. See generally JoRdAN SCHWARZ, Liberal: AdOLF A. BERLE AND THE VISION OF AN AMERICAN ERA (1987). For Berle's focus on foreign affairs in his writing between 1919 and 1923, see the thirteen articles listed in that period in the bibliography, The Published Works of Adolf A. Berle, 64 CoLuM. L. REV. 1372, 1373 (1964) [hereinafter Published Works]. Between 1923 and 1931, Berle published fourteen law review articles on corporate law, mostly in the Harvard and Columbia Law Reviews. Id.

4. See generally MCPP, supra note 2.

5. See generally Merrick Dodd, For Whom are Corporate Managers Trustees?, 45 HARV. L. REV. 1145 (1932) and Adolf A. Berle, For Whom Corporate Managers Are Trustees: A Note, 45 HARV. L. REV. 1365 (1932), which were published respectively in the May and June 1932 issues of the Harvard Law Review after the Berle and Means book had been finished but before its publication and just as Berle began working on FDR's campaign. Dodd's piece had been a response to an earlier article by Berle published the prior year. See Adolf A. Berle, Corporate Law as Powers in Trust, 44 HARV. L. REV. 1049 (1931). William Bratton and Michael Wachter have shown that the actual 1932 exchange between Berle and Dodd does not have as much purchase for the contemporary 
member of the brain trust for Franklin Roosevelt (and the speechwriter for the candidate's important Commonwealth Club Speech during the fall campaign), Berle's voice helped elect a President and bring in the New Deal with its massive changes in American government. ${ }^{6}$ For the thirtyseven-year-old law professor, those three accomplishments in one year amounted to an intellectual trifecta.

Somewhat surprisingly, Berle did not go into the new Administration after the election, as did other brain trusters. Rather, he went back to New York City to his law practice and teaching at Columbia and being a brain truster for Fiorello LaGuardia in the 1933 and 1937 mayoral campaigns. In between he served as Chamberlain for the city (the last Chamberlain before the job was abolished), all the while maintaining access to the President, taking on specific tasks for him, and regularly helping develop and explain economic policy. ${ }^{7}$ Berle joined the Roosevelt Administration full time in 1938 as Assistant Secretary of State, staying for the next seven years and then an additional year as U.S. Ambassador to Brazil. His portfolio still reflected his access to the President and presidential assignments, including some delicate matters related to intelligence and alleged communist infiltration. He was positioned to have a key role in planning the post-war international economic structure, which was ongoing from the time war broke out in Europe in mid-1939. This process led to the creation of the International Monetary Fund, the World Bank, and the World Trade Organization that provide the basis for contemporary international interaction in monetary affairs, development, and trade. One of the earliest meetings with John Maynard Keynes on the British side took place in Berle's office, and he was a key link in discussions with the British about post-war economic matters. ${ }^{8}$

After the war, with a new President and a new set of presidential advisers, Berle returned to New York City to teach at Columbia, work with foundations, and generally pursue the role of a public intellectual. ${ }^{9}$ Having essentially stopped publishing in law reviews ${ }^{10}$ and producing little in the

shareholder/stakeholder primacy discussions as modern writers may see. The two professors were on different wings of a then-current corporatist approach to corporate theory and each writer later changed his position in ways that blur where they would stand in the modern debate that invokes their names. See generally William W. Bratton \& Michael L. Wachter, Shareholder Primacy's Corporatist Origins: Adolf Berle and the Modern Corporation, 34 J. CORP. L. 99 (2008).

6. See William W. Bratton, The Modern Corporation and Private Property Revisited: Gardiner Means and the Administered Price, 42 SEATTLE U. L. REV. 591 (2019) (discussing the Commonwealth Club speech and Berle's role in the campaign).

7. See infra Part I.

8. See infra Part II.

9. See infra Part III.

10. See Adolf A. Berle, Stock Market Manipulation, 38 ColuM. L. ReV. 393 (1938). See generally Published Works, supra note 3. There were two law review articles in the 1933-1945 period: 
way of books ${ }^{11}$ during the twelve years of the Roosevelt Administration, Berle again picked up his writing. Much of Berle's law review writing of the post-war period returned to specific aspects of corporate law. ${ }^{12}$ The books picked up on the themes of MCPP but the corporatist threads of the earlier work had given way to what Bill Bratton has called a happier story where "big stick" government had emerged to keep corporations in line. ${ }^{13}$ By the time of Berle's death in 1971, this political economy approach had been challenged by competing ideologies, including what would become the market-based deregulatory corporate law theories that flowered during the 1980s. ${ }^{14}$

The political history of the period enhances the understanding of the evolution of Berle's career. In the 1920s he was still gathering ideas and data about structural changes in the corporate space in a post-industrial revolution economy. His focus was on building-out a new understanding of corporate finance in an economic environment where the Berle and Means corporation held center stage. ${ }^{15}$ Even so, most of his ideas for reform clustered around protecting shareholders against management overreaching, ideas that by themselves in the "normalcy" of the 1920s would not have commanded lasting attention. Yet, with the return of a progressive Democrat to the presidency, and the transformative expansion of the federal government in the wake of the unprecedented economic

one a five-page printing of his commencement remarks at Cornell Law School in 1938 and the other a fourteen-page, post-1934 follow-up of his 1931 article on liability for stock market manipulation. Id.

11. See Published Works, supra note 3. Between 1933 and 1945 he published a new edition of his casebook on corporate finance (with a co-author), a short French tract on man and property, a twenty-one-page book: ADOLF A BERLE, JR., NATIONAL REALISM AND CHRISTIAN FAITH (1940), and a book on liquidity, co-authored with a student, that addressed new forms of liquidity for property including particularly ownership of shares in modern corporations. Two books from this period related to his government service are addressed later in this Article: one a book based on his testimony to TNEC in 1939 regarding government providing of capital and the other his 1940 book, NEW DIRECTIONS AND THE NEW WORLD, based on a series of articles he had written about the state of world affairs. See infra note 63; SCHWARZ, supra note 3, at 211 and accompanying text.

12. For example, a 1952 article on corporate personhood reflects some of the big picture ideas of the separation of ownership and control brought forward a couple of decades with analysis of links to contemporary debates on constitutional rights of corporations. Adolf A. Berle, Jr., Constitutional Limitations on Corporate Activity-Protection of Personal Rights from Invasion Through Economic Power, 100 U. PA. L. REV. 933 (1952). Other articles address control theory in corporations and enterprise liability that seem to grow out of early Berle. See Published Works, supra note 3.

13. Bratton, supra note 6. Bratton discusses Means's focus on administering prices - in Means's dissertation but omitted from MCPP, yet essential to understanding the ideas in the book.

14. A conference held at Stanford in 1982 on the 50th Anniversary of the publication of MCPP represents the new movement's challenge to Berle and Means. See Conference, Corporations and Private Property, 26 J. L. ECON. 235 (1983). Bill Bratton's contribution in this symposium discusses Means's participation in that conference and the newcomers' challenge to the Berle and Means thesis evidenced at that conference.

15. See Brian R. Cheffins, The Rise and Fall (?) of the Berle-Means Corporation, 42 SEATTLE U. L. REV. 445 (2019). 
calamity of the Great Depression and then world war, there was room for new approaches. The New Deal essentially added one new financial statute per year until the outbreak of World War II that cumulatively sought to bring more social control over finance. ${ }^{16}$ Berle's explanations provided fertile ground to support the growth of such broad change. ${ }^{17}$ During this time, Berle was in (or within sight of) the mainstream of political developments. Thereafter, politics became too wide and too deep; his sallies into the larger political space were briefer and fewer and he spent more time in the protected coves of foundations and the university. ${ }^{18}$

Berle's personal traits certainly shaped his political role and he surely benefited from another political development of the period-changes in the staffing of the presidency and the executive branch that made room for the brain truster role he most valued. He served such a function for David Lilienthal in Wisconsin before FDR and for LaGuardia in New York City afterwards. ${ }^{19}$ The term, however, does not necessarily suggest a precise definition. For Berle, it meant a freelancer as to ideas and a free agent. As he described himself in a letter after the election in 1932, "I shall choose merely ... being an intellectual jobber and contractor from time to time when jobs come forward." ${ }^{20}$ This was "to have in life the thing that he most wants." 21 The "free" part seems to have been key. Full of ideas, he believed

16. This legislation included the following: Securities Act of 1933, Pub. L. No. 73-22, 48 Stat. 74; Securities Exchange Act of 1934, Pub. L. No. 73-291, 48 Stat. 881; Public Utility Holding Company Act of 1935, Pub. L. No. 74-333, 49 Stat. 803; 1938 Amendments to the Bankruptcy Act of 1898 (the Chandler Act), Pub. L. No. 75-696, 52 Stat. 840; 1938 Amendments to the Securities Exchange Act of 1934 (the Maloney Act), Pub. L. No. 75-719, 52 Stat. 1070; Trust Indenture Act of 1939, Pub. L. No. 73-291, 48 Stat. 881; Investment Company Act of 1940, Pub. L. No. 76-768, 54 Stat. 789; Investment Advisers Act of 1940, Pub. L. No. 76-768, 54 Stat. 847.

17. There is something of a disconnect between Berle's early corporate law writings from the 1920 s and his responses to the Depression. Both are contained in MCPP and the relationship is sometimes hard to reconcile. William Bratton and Michael Wachter, in a series of articles singly and together, have provided a helpful typology identifying "early", "middle", and "late" Berle. Both early and middle Berle are interspersed in $\mathrm{MCPP}$ - a disconcerting result — but one that reflects the changing political trends in the wake of the economic calamity at the end of the 1920s. See Bratton \& Wachter, supra note 5 , at 121 .

18. This analogy derives from an insight of Dan Ernst.

19. See SCHWARZ, supra note 3, at 72.

20. Letter from August A. Berle to John Hanna, Columbia Law Professor (Nov. 16, 1932), in NAVIGATING THE RAPIDS 1918-1971, at 80-81 (Beatrice B. Berle \& Travis Beal Jacobs eds., 1973) ("[S]hort of some particular set of circumstances imposing a real obligation, I should be merely foolish to trade this for the mazes of official life in Washington."). For Berle's use of this "intellectual jobber" term in a different context, see Harwell Wells, "All Lawyers are Somewhat Suspect": Adolf A. Berle and the Modern Legal Profession, 42 SeattLe U. L. ReV. 641 (2019).

21. Letter from August A. Berle to John Hanna, in NAVIGATING THE RAPIDS, supra note 20, at 81. 
he could take on a wide range of issues and then was on to the next challenge, often without the need to stay long on a particular topic. ${ }^{22}$

At the same time, other personal traits limited his effectiveness in the roles he undertook after 1932. He was unquestionably smart. He believed he could do almost anything: solve the sugar problem in the Dominican Republic; become a Russian expert simply by stepping behind a desk at an Army hall in World War I; join in the heady days of peace talks with little more than university degrees. ${ }^{23}$ Two other qualities, however, limited his effectiveness. First, he regularly preferred one-off tasks, serving as the intellectual jobber and free-lancer that he described in his 1932 explanation as to why he would go back to New York City. Implementation of policy did not hold nearly the attraction for him that ideas or solving a particular problem did. Even when he went to the State Department (in 1938 and again in 1961 as discussed below), he thought he could do what needed to be done in six months and then be on to something else. The semester-long period of a professor's typical class may have been his optimal time target. Second and probably a side effect of the first quality, it was a challenge for him to work as part of a team. As a New York newspaper columnist concluded, when Berle went to Washington, "the widespread conviction that Berle is just as good as he says doesn't make him any easier to take." ${ }^{24}$ Co-workers found him a challenge, not just for his ego and vanity but also for his impact on team production. "He works in every direction, with or without instructions," one colleague said; "Berle's sphere of activity is still more or less of an enigma." 25 His strengths that stood out in drafting speeches for the President or presenting the structure of an academic article worked less well in a two- or threeyear process to build out a detailed system of post-war international economic agencies. Berle's quick mind didn't give him the detailed

22. His biographer, Jordan Schwarz, includes an example of how Berle "acquired expertise quickly" as "a clever man bent upon capturing the ears of men in power." See SCHWARZ, supra note 3, at 23-24. As Berle told the story in an oral history at Columbia Law School in 1969, he was at the Army War College near the end of World War I awaiting reassignment after service in the Dominican Republic. The officer at the desk where Berle was standing received orders for Siberia and immediately left the building. Berle assumed the position behind the desk and was confronted by an orderly with a colonel's request for the current exchange rate of Finnish marks. Berle retrieved a newspaper from the trash, answered the colonel's question, and soon received several additional queries which Berle answered. When the colonel subsequently appeared to see who had been answering his questions, he made Berle his "expert" on Russian economics. See Transcript of Oral History Interview: Reminiscences of Adolf A. Berle, Jr.: Oral History 32-34 (1969) (on file at the Oral Research Office of Columbia University) [hereinafter Reminiscences].

23. See supra infra Parts I-II; sources cited note 22.

24. Rodney Dutcher, In Washington, TelegraPh-HeRAlD, Feb. 16, 1938, at 6. author).

25. Diary of Breckenridge Long, Assistant Secretary of State 233 (Dec. 20, 1940) (on file with 
knowledge of monetary control and trade restrictions that the international process needed.

\section{INFLUENCING THE NEW DEAL FROM NEW YORK CITY, 1933-1937}

After the election in 1932, other prominent members of the brain trust entered the Administration-Raymond Moley as Assistant Secretary of State, for example, and Rexford Tugwell as Assistant Secretary of Agriculture. Berle continued to be based in New York, teaching law at Columbia and practicing law with his brother. ${ }^{26}$

That did not keep him from regular tasks for the President. During the period between the election and inauguration (then a four-month period, six weeks longer than the current transition), Berle worked on railroad reorganization, sparking a disagreement with another FDR advisor from academia, Felix Frankfurter, his former professor. ${ }^{27}$ Berle was willing to acknowledge the reality of size in the modern economy and have government regulate big corporations while Frankfurter's approach was aligned with the Brandeisian model of breaking up large entities to enhance competition among small participants. ${ }^{28}$ Right after the inauguration, Roosevelt designated Berle and others to meet at Treasury with the Federal Reserve, private bankers, and others on the banking crisis. Berle was named secretary of a subgroup of five to develop a specific scheme for Congress. ${ }^{29}$ Over the first six months of the new Administration, he commuted from New York as a special assistant on railroad matters to Jesse Jones, chair of the Reconstruction Finance

26. Berle also served on the advisory board of the New York Stock Exchange during his time in New York, among other activities.

27. See Diary of Raymond Moley (Jan. 11, 1933) (on file with Raymond Moley Papers, Box 1) (noting Berle's conversation with Moley including Berle expressing the view that Frankfurter was out to ruin him). In a letter to FDR about Frankfurter's intervention, Berle signed the letter: "Yours truly, in a mean state of mind, with considerable admiration for F.F's public career and an intense personal desire to see him shot." Letter from Adolf A. Berle to Franklin Roosevelt, in NAVIGATING THE RAPIDS, supra note 20, at 83. The Berle-Frankfurter relationship, seemingly, was never good. Frankfurter had joined the Harvard law faculty during Berle's second year as a law student. See Roscoe Pound, Frankfurter at Harvard, in FRANKFURTER, A TRIBUTE 137 (Wallace Mendelsohn ed., 1964). Joseph P. Lash, in a biographical essay accompanying the Diary of Felix Frankfurter, suggested, "There was always an edge to Berle's opposition, a touch of resentment, at having been excluded from Frankfurter's little elite group of disciples at Harvard Law School." Joseph B. Lash, Biographical Essay, in From the Diary OF Felix FranKfurTer 44 (Joseph P. Lash ed. 1975). Jordan Schwarz suggested the student had given offense to the somewhat older professor: "Their ambition seemed to need each other's enmity." SCHWARZ, supra note 3, at 15.

28. See Telegram from Frankfurter to Raymond Moley (Jan. 12, 1933) (on file with Raymond Moley Papers, Box 68) ("[I] am greatly disturbed after talking with Berle lest governor be embarrassingly involved in support of railroad reorganization bill ...."). A reorganization bill passed on the last day of the Hoover Administration. This disagreement between Berle and Frankfurter reappeared at various points in the future.

29. SCHWARZ, supra note 3 , at 86. 
Corporation. He resigned that position September 1 when Roosevelt sent him with Sumner Welles (later the Undersecretary of State who brought Berle to the State Department) on a special mission to Havana to deal with Cuban instability. ${ }^{30}$

Throughout this early period, Berle was central in developing core economic ideas of the New Deal. He shared with other brain trusters, Moley and Tugwell, a faith in more state planning for the economy. Early on this was evidenced in the corporatist planning approach of the National Industrial Recovery Act that was passed in the first hundred days of the New Deal providing space for corporations collectively to decide on rules for competition. ${ }^{31}$ This centerpiece of the early New Deal industrial policy empowered the National Recovery Administration to oversee broad industry agreement on prices and other matters, but ultimately proved unsuccessful in practice even before it was struck down by the Supreme Court in $1935 .^{32}$ During FDR's second term, as the economic malaise continued, Berle embraced the Keynesian idea of government spending to stimulate the economy. Throughout the first two terms, Berle advocated for multiple means to provide more state capital, a view shared by Jesse Jones, whose Reconstruction Finance Corporation financed multiple New Deal programs. Berle looked to others with similar ideas including, for example, Robert Moses, whose planning for New York City was just beginning to takes shape when Berle was Chamberlain, and Hjalmar Schacht, the finance chief of the Third Reich until $1937 .{ }^{33}$ The idea of using government capital to enhance the growth of private corporations was an idea that Berle shared with John Maynard Keynes even before the specific interactions between the two discussed in Part II.

These tasks and the ideas Berle wrote about provided him a seat at the table but did not make him a major actor in FDR's now famous first hundred days. Berle had a public role in the debate around each of the economic ideas just discussed, although (equally as telling) he had no significant role in drafting any of the statutes of 1933 or thereafter or in organizing the agencies that were created to administer the burgeoning administrative state, other than a brief stint at the RFC in 1933.

30. Id. at $82,90-91$.

31. National Industrial Recovery Act, Pub. L. No. 73-67, 48 Stat. 195 (1933).

32. A.L.A. Schechter Poultry Corp. v. United States, 295 U.S. 495 (1935). See generally ELLIS Hawley, The New Deal and the Problem of Monopoly 28 (1995). See also id. at 460-61 (describing an early version of the planning orientation - versus competition enhancing or spendingas set forth by Berle in a widely publicized memorandum in July 1938 discussing the lines of inquiry that TNEC might pursue, in which Berle argued TNEC should not assume that all monopoly was bad, that cartels were necessarily harmful, that small business was necessarily competitive or necessarily humane, or that big business necessarily grew by predatory tactics, and it should realize that there were immense practical difficulties in the way of applying the theory of an "elastic price").

33. See SCHWARZ, supra note 3, at 119. 
For example, in the drafting of the Securities Act of 1933, Roosevelt had instructed two different groups to prepare drafts in the period after his election in $1932 .{ }^{34}$ After the resulting legislation ran into difficulty when it got to Congress soon after the inauguration, the President quickly moved to a third group (Felix Frankfurter et al.) who quickly came to Washington for a weekend drafting session that produced the legislation that eventually passed Congress in the first hundred days. ${ }^{35}$ Berle, over that winter, had received a grant from the Commonwealth Fund for a project on state securities laws and would have been as well situated substantively as Frankfurter to take on the task. ${ }^{36}$ Berle later told William O. Douglas, his former colleague on the Columbia faculty, "I have always felt unhappy that our good friend, Felix Frankfurter, who knows next to nothing about the subject except on paper, felt that he had reached the final and everlasting answer." 37

Berle had more interest in a federal incorporation bill that would have enacted a federal law of corporations, having drafted a bill for a House committee during the transition. ${ }^{38}$ A year later he wrote to Douglas, then a law professor but soon to be SEC chair and later a Supreme Court justice: "Confidentially, we are working on a federal incorporation law, which I hope will be presented to Congress in the next session." ${ }^{39}$ Implementation is often more difficult than proposing; this idea failed to make it into the Securities Exchange Act of 1934 or any federal legislation since. Frankfurter, who was in England on leave from the Harvard law faculty, had a greater role in the drafting of the 1934 Act than Berle. Similarly, the breakup of public utilities and various new regulatory regimes for investment advisers, mutual funds and broker-dealers all went forward without Berle. ${ }^{40}$

Berle's access to Roosevelt did provide him with a recurring role in policy discussions including, for example, those between Supreme Court Justice Louis Brandeis and Roosevelt. Berle's connections with Brandeis

34. One version came from the work of Samuel Untermyer who had a prominent role in hearings during what had been the most recent Democratic Administration and the other by Huston Thompson, a former chair of the Federal Trade Commission. See ARThur Schlesinger, JR., The Coming OF THE NEW DEAL 1933-1935, at 440 (Houghton Mifflin Co. 1958).

35. SCHWARZ, supra note 3, at 82.

36. Minutes of Legal Research Committee of the Commonwealth Fund (Oct. 22, 1932).

37. Letter from Adolf A. Berle to William O. Douglas (Dec. 30, 1933) (on file with author).

38. SCHWARZ, supra note 3 , at 82.

39. Id.

40. This is not to say that Berle did not offer ideas. See Letter from Adolf A. Berle to Benjamin Cohen (Dec. 8, 1934) (on file with Records of the Department of the Interior, Record Group 49, Box 9, National Public Power Committee (Entry 907)) (enclosing "miscellaneous remarks on the general subject of holding companies"); see also Letters to Felix Frankfurter from Secretary of the Treasury William Woodin and Representative Sam Rayburn concerning the Securities Act of 1933, in NAVIGATING THE RAPIDS, supra note 20, at 86-87. 
dated back to his youth. Adolf A. Berle Sr. was a Congregationalist minister in Boston and aligned with Brandeis in progressive causes. ${ }^{41}$ The elder Berle provided written testimony for Brandeis during his highly contested four-month confirmation process in 1916 that made him the first Jewish justice on the Supreme Court. ${ }^{42}$ Berle's first job after graduating from Harvard Law School that same year (a connection in which his father assisted) had been at the Brandeis firm, where he practiced for a year before joining the army when the United States entered World War I. ${ }^{43}$ Even so, there was a large gulf between how Berle and Brandeis viewed the best response to incorporated enterprises that had come to dominate the economy since the Civil War. Brandeis long favored breaking up the big entities through antitrust and otherwise while Berle recognized the seeming inevitability of the corporate form and sought ways to combat them, particularly via government controls. This approach was part of the corporatist approach described earlier. Berle did not confront Brandeis on these differences, but neither did he accede to the justice's preferred economic solution. ${ }^{44}$

The New Deal's legislative agenda faced intense headwinds from the Supreme Court during Roosevelt's first term, and Roosevelt had no opportunity to make an appointment to the Court until August $1937 .{ }^{45}$ At times, Roosevelt could not even count on the support of Brandeis, Benjamin Cardozo, or former Columbia Law dean Harlan Fiske Stone. In

41. The Brandeis Letters contain several letters of Brandeis to the elder Berle and other references to common causes. See 2 BRANDEIS LETTERS, supra note 1, at 91 (Feb. 26, 1908), 152 (Sept. 27, 1906), 161 (May 20, 1908). See generally MCCP, supra note 2.

42. See S. REP. NO. 66-409, at 294-95 (1916) (containing letter of Adolf A. Berle of February 18, 1916: "many of the interests represented by the protesting gentlemen are now and have been ever since I have resided in the Commonwealth, against any emergence into public influence and power of anyone not of their number and clan. ... [Brandeis] would adorn the bench and add to the glory ... of the greatest court in the world").

43. Berle's oral history at Columbia describes the elder Berle's reaching out to Brandeis after the younger Berle saw a notice of a job opening at the Brandeis firm. See Reminiscences, supra note 22, at 18. The Brandeis Letters contain a letter from Brandeis to the elder Berle responding to Berle Sr.'s letters of January 24, 1906 and January 30, 1906 regarding Berle Jr. and congratulating Brandeis (after the announcement by President Wilson of his nomination of Brandeis to the court). The Brandeis response on February 9, 1916 said, "It is a great pleasure to have your letter[s] of the $24^{\text {th }}$ and $30^{\text {th }}$ as it was recently to meet your son and to be reminded of our more frequent meetings years ago." 4 BRANDEIS LETTERS, supra note 1 , at 36.

44. Berle wrote to Justice Brandeis in 1923 seeking advice on whether he should take on a particular client, but the exchange probably indicates the lack of mentors Berle had at the time more than particular closeness between the two. See 5 BRANDEIS LETTERS, supra note 1, at 101 (Sept. 28, 1923).

45. After a continuing string of non-success before the Court into 1936, Roosevelt launched his Court Packing Plan in the winter after the election that year. The plan was rejected by the Senate in mid-1937, but within a month Roosevelt made his first appointment to the Court with six more following over the next four years. See also A. C. Pritchard \& Robert B. Thompson, Securities Law and the New Deal Justices, 95 VA. L. REV. 841 (2008). 
the spring of 1934, Brandeis told Jerome Frank that he wanted to see Berle and Tugwell; after meeting with the justice, Berle reported to the President of Brandeis's concerns about New Deal Programs. ${ }^{46}$ During that summer, Brandeis summoned Berle to his vacation home on Cape Cod to again express worry about an approach allowing concentration in the economy and the merits of an Administration response centered on balancing such concentration with government power as opposed to decentralizing. ${ }^{47}$ In September, at Roosevelt's invitation, Berle participated in a discussion including the President, SEC chair Joseph Kennedy, and a railroad president at Hyde Park about the Administration's approach to concentration in the economy. ${ }^{48}$

During this time, when not performing tasks for the President, Berle was actively engaged with Fiorello LaGuardia's campaign to become mayor of New York, an election that took place in November of $1933 .{ }^{49}$ Arguing on behalf of the reforming Republican against a weak Tammany incumbent and an anti-Tammany Democrat whom FDR could have backed, Berle played a key role in keeping the President neutral. ${ }^{50}$ LaGuardia won the election with a plurality of the vote and offered Berle the job of chamberlain of the City where he could take on the task of coordinating the response to the city's financial crisis. The position was made for a brain truster. Berle biographer Jordan Schwarz described it as providing the "opportunity to delve into anything he and LaGuardia considered fair game." 51 Berle described the job as permitting him "to cover a good deal of general brain trusting for the Administration on a wide variety of subjects including elevator strikes, transit unification, the

46. Letter from Adolf A. Berle to Franklin Roosevelt (Apr. 23, 1934), in NAVIGATING THE RAPIDS, supra note 20, at 95 ("Mr. Justice Brandeis has been revolving matters in his head and I think requires some attention."). Berle's letter opened with the greeting "Dear Caesar," a salutation Berle was prone to use until Roosevelt sent word in the heat of the court-packing dispute to desist. See Berle Diary (Mar. 4, 1937), in NAVIGATING THE RAPIDS, supra note 20, at 125.

47. SCHWARZ, supra note 3, at 106. Berle was not directly involved in perhaps the most-pointed message from Brandeis to Roosevelt. After the Schechter decision in 1935, Brandeis told Corcoran and Cohen, "This is the end of this business of centralization, and I want you to go back and tell the president that we are not going to let the government centralize everything." Supra note 32 and accompanying text; see JefF SHesol, Supreme Power, Franklin RoOsevelt V. The SuPREME COURT 551 n.132 (1939) (quoting Harry Hopkins, "Statement to Me by Thomas Corcoran Giving His Recollections of the Genesis of the Supreme Court Fight").

48. SCHWARZ, supra note 3, at 106.

49. See George Whitney Martin, CCB: The Life And Century of Charles C. BURLINGHAM, NEW YORK's FIRST CITIZEN, 1858-1959, at 339-40 (2005) (describing Berle in a group of four reform leaders that helped LaGuardia to power).

50. See Letters from Adolf A. Berle to Arthur Mann (Mar. 31, 1965 \& Apr. 21, 1965), in NAVIGATING THE RAPIDS, supra note 20, at 89 ("Roosevelt considered he had a half-commitment to support [Democratic candidate Joseph] McKee ... . I like to think I neutralized his influence .... Roosevelt said nothing-and stayed out.").

51. SCHWARZ, supra note 3 , at 96. 
rehabilitation of the credit of the City of New York, salvaging the real estate mortgage bond situation, and so forth." 52

\section{MOVING INSIDE THE ADMINISTRATION: THE STATE DEPARTMENT, 1938-1944}

\section{A. Initial Expectations}

There were recurring efforts to get Berle to Washington. Undersecretary of State Sumner Welles pushed during 1937 for Berle to join the State Department. ${ }^{53} \mathrm{He}$ had the good sense to make the pitch to Berle as a position that would permit double brain trusting, for both the President and the State Department. ${ }^{54}$ What evolved was a mix of economics, diplomacy, and politics that appealed to Berle's free agent/intellectual jobber approach to life.

The Great Depression hung on despite New Deal efforts (including a second new deal in 1935-1936) and the economy took another dip in the fall of 1937 through most of 1938. After LaGuardia's reelection and with the economy suffering, Berle was among eight men-industrialists, union leaders, and brain trusters - who gathered at the Century Club in New York in December 1937 to debate possible changes in the Administration's economic policies. Most of the group then met with the President early in the new year pushing broader federal spending, although the effort failed to gain much traction. ${ }^{55}$

As Berle began work at the State Department after he was confirmed by the Senate on March 4, 1938, he continued to be active in formulating economic policy. In 1939, for example, he testified before the Temporary National Economic Committee, a joint group of members of both houses of Congress and cabinet/agency representatives, on proposals for access to capital; he suggested, for example, a bank where government agencies could go for public works or congressional creation of a capital credit bank for public or private enterprises in need of financing not available via private lending - all ideas consistent with the state-provision of capital that was a familiar Berle theme. ${ }^{56}$

Similarly, Berle continued to be active in politics during his time at the State Department. For example, he made a trip to Colorado to speak to Democrats in August of 1939 and to Texas in February of the following

52. SCHWARZ, supra note 3, at 97.

53. Berle Diary (Apr. 29, 1937), in NAVIGATING THE RAPIDS, supra note 20, at 126.

54. See SCHWARZ, supra note 3 , at 110 .

55. NAVIGATING THE RAPIDS, supra note 20, at 154-57, 159-60.

56. Ernest K. Lindley, The Capital Bank, Mr. Berle's New Idea, WASH. Post, May 28, 1939, at 9 . 
year. ${ }^{57}$ Of course, his day job was in the Department entrusted with American foreign affairs and he had been hooked on diplomacy since his World War I experience. After joining the Army when America joined the war, Berle was sent to the Dominican Republic to secure legal title to Dominican sugar for United States interests, an experience that engendered a lifelong interest in Latin America and in foreign affairs. ${ }^{58}$ Berle's experience in Paris, when the Army rushed him and many others for the sudden arrival of peace negotiations in 1918, impressed upon him (and many others in the American government) the need to plan for peace in an entirely different way when faced with another world war. Prior to his State Department tenure, Berle had been an American commissioner to the 1936 Buenos Aires conference on peace in the hemisphere, also attended by the President and Secretary of State Cordell Hull. ${ }^{59}$ The conference, which reflected the Administration's Good Neighbor policy, sought to create a tighter bond between the U.S. and the Americas at a time of darkening clouds internationally. Berle's continuing interest in Latin America and his resistance to British trade restrictions and its imperialistic desires could be seen in this period and later when he got to the State Department.

But even the diplomatic tasks he undertook once he joined the Administration as Assistant Secretary - a trip to Lima for an InterAmerican Conference in 1938, negotiating a deal with Canada regarding the St. Lawrence Seaway, speechwriting after the Munich Conferencehad a strong flavor of one-off tasks of a freelancer. ${ }^{60} \mathrm{~A}$ British foreign office reported, "Neither I nor anyone else I know of, has any idea of why Mr. Berle was appointed or what he did in office .... [H]e has told me that he was engaged in economic work, and was attending to no routine matters at all." $" 61$

Consistent with that approach, Berle did not see himself staying long at the State Department-perhaps six months in his original conception. As that period was running out, and after he had submitted a resignation

57. See infra notes 81,86 and accompanying text.

58. See Reminiscences, supra note 22, at 5.

59. See Beatrice Bishop Berle Diary (Dec. 2, 1936), in NAVIGATING THE RAPIDS, supra note 20, at 119.

60. See SCHWARZ, supra note 3, at 123-28, 147-55.

61. SCHWARZ, supra note 3, at 123-24. Such a status was not unprecedented. Ray Moley had been Assistant Secretary of State at the beginning of the Roosevelt Administration with no diplomatic duties. Rather, he spent his time in the early months as the primary intermediary between the Administration and Congress as to the legislative project of the first hundred days. Even so, Moley's lack of connection to the Secretary and the Department likely hurt him when the planning and implementation of the London Economic Conference in mid-1933 took unexpected turns, leading to his resignation. See Albin Krebs, Raymond Moley, Roosevelt Aide, Dies; Brain Trust Leader Coined "New Deal”, N.Y. TIMES, Feb. 19, 1975, at 35. 
letter to the President, he got caught up in the Czechoslovakian crisis. ${ }^{62} \mathrm{He}$ helped advise Secretary of State Hull and write the President's speech after the Munich agreement and his resignation was delayed. ${ }^{63}$ After going to Lima as a commissioner to the Inter-American conference in December 1938 , he took a leave of absence for six weeks or so to ponder approaches before returning to daily work at the Department. During 1940, Berle again expressed his expectation to return to New York after the election. ${ }^{64}$

Over this period of his early time at the State Department, three developments reset his decision space, extended his tenure, and changed the focus of his work. The most dramatic change, of course, was the outbreak of war in Europe in mid-1939 and the fall of country after country in the spring of 1940, leaving the United Kingdom seemingly isolated against the Axis. ${ }^{65}$ But it was not just a change in world events; there were unexpected political changes afoot in domestic politics as a possible third term for Franklin Roosevelt was broached and moved to reality. After his trip to Colorado in August of 1939, Berle reported to Roosevelt that Democrats there saw the choices as a third term or Hull. ${ }^{66}$ Before going to speak to Texas Democrats in February of 1940, Berle went to see the President, so as to be warned off of any incorrect messages in the anticipated speech. Berle then told the Texans, "I do not think the President wants a third term" but would accept a draft. ${ }^{67}$ Three weeks before the election he was summoned to the White House for campaign speech-writing duties: "It was the old Brain Trust back again, except the scene was the Cabinet Room instead of the Hotel Roosevelt." ${ }^{68}$ Berle was to serve the third term in D.C. but his focus changed. Economics was still a key topic, but world events made it more international than domestic and more focused on structuring a new approach to international economic relations.

62. See Letter from Adolf A. Berle to Franklin Roosevelt (Aug. 16, 1938), in NAVIGATING THE RAPIDS, supra note 20, at 181-82.

63. Berle Diary (Sept. 14, 1938), in NAVIGATING THE RAPIDS, supra note 20, at 184-85 ("The Secretary also asked the President if he would hold my resignation until we saw where this came out, which the President promptly agreed to do.").

64. SCHWARZ, supra note 3 , at $125,142$.

65. By the fall of 1940, in a letter to Columbia University president Nicholas Murray Butler, Berle said, "there is no more fascinating place in the world than the State Department, just now." SchwARZ, supra note 3, at 125 (citing Berle Diary (Oct. 11, 1940), on file with the Franklin D. Roosevelt Library, Berle Papers, Box 30).

66. Berle Diary, Memorandum to the President (Aug. 14, 1939) (on file with the Franklin D.

Roosevelt Library, Berle Papers, Box 66).

67. SCHWARZ, supra note 3, at 142.

68. Id. 


\section{B. Designing the Post-War Economic Structure for the World}

With the outbreak of war in Europe and the increasing likelihood of a third term for Roosevelt, Berle's time horizon for his tenure in government lengthened and the pursuit of a new international economic structure occupied a large and continuing place in his work. This Part first outlines the general approach that Berle and other New Dealers had in addressing these problems, the evolving understanding of economics in the world order, and the competition between different parts of the Administration to plan this structure. Subsequent Parts outline the evolution of this planning and Berle's role in it focusing on the distinctively different tenor of the early part of this period from the later part.

\section{Laying Down a Marker: This Time Would Be Different}

Berle, Roosevelt, and other New Dealers who had seen the peace process after World War I up close approached their task in a new war resolved that it would be different for them; the time for making peace was during the war, not after it. Berle had initially served in the Dominican Republic in World War I, as discussed above. He arrived back in Washington for a new assignment just as the war ended and a mad scramble began to negotiate the peace. ${ }^{69} \mathrm{He}$ was among a large number of army officers dispatched to Paris, talking his way into a room at the main hotel, joining a group of then-youthful officers who would go on to high positions in American government-John Foster Dulles, Allen Dulles, William Bullitt; Berle, with Bullitt and others were the "jeunesse radicales" who had protested the penal nature of the peace that constricted post-war development. ${ }^{70}$

Franklin Roosevelt, then Assistant Secretary of the Navy, formed his own perception of the process that shaped his own approach as President. ${ }^{71}$ Berle and Roosevelt had conversations on these issues going back to the 1932 campaign. ${ }^{72}$ John Maynard Keynes, to become a key player on the

69. Reminiscences, supra note 22 , at 32-34.

70. Berle Diary (Dec. 7, 1918), in NAVIGATING THE RAPIDS, supra note 20, at 7-8; see also ARTHUR M. SCHLESINGER, JR., The CRISIS OF THE OLD ORDER, 1919-1933, at 11-12 (1988) (describing “a young man's world at Versailles" including Berle as "acting chief of the Russian section").

71. Roosevelt was not part of the official delegation to the Peace Conference but visited Europe while it was going on. He was a fellow-traveler on the U.S.S. George Washington to the United States when the President took a brief break from his four-month attendance at the conference. During the voyage, the future President joined conversations about the League of Nations with the incumbent President. See Frank Freidel, Franklin D. RoOsevelt, A RendeZvous With Destiny 31 (1990) (describing Roosevelt's luncheon with Wilson).

72. SCHWARZ, supra note 3, at 211. 
British side in the negotiations to come, had argued in the earlier period for American wealth to bankroll the reconstruction of Europe ${ }^{73}$ He was not successful in blocking a penal peace coming out of the Versailles conference, but his book on the deficiencies of the peace process increased his stature. ${ }^{74}$ His challenge to the neoclassical paradigm as to government's role in priming the economy from his 1936 book, The General Theory of Employment, Interest and Money, influenced New Deal efforts on spending in 1938 and thereafter. From mid-1940, he was a key figure for the Treasury on the British side in the process described in the following section.

Berle continued to have a highly visible profile. His 1940 book, New Directions in the New World, written in part during his State Department sabbatical, supported a post-war economic system in which American wealth would play a role similar to what Keynes had suggested for the post World War I period. ${ }^{75}$ Another book that year, by Joseph Alsop and Robert Kintner, relied on Berle's unpublished diaries in examining American diplomacy after the Munich crisis, suggesting America could be drawn into war. $^{76}$

In 1941 Berle was active in several important pre-war issues for the American President. Early in that year, a fight between State and Treasury on freezing foreign assets while America was still neutral went to the White House where Roosevelt upheld Berle and the State Department's view against such action. ${ }^{77}$ Berle also played a key role in early 1941 in securing Canadian acquiescence to an agreement for the St. Lawrence Seaway. During talks in Ottawa, where Berle initialed the agreement for the United States, Berle seemed to build Canadian interest for more integrated defense and economic planning involving the two neighbors. Later that spring in a meeting at Roosevelt's home at Hyde Park, the Canadian prime minister secured Roosevelt's assent for American lendlease to, in effect, subsidize U.K. purchases from Canada, a concession that seemed to dull the Canadian interest in Berle's larger plans for integrated government planning. ${ }^{78}$

73. Berle describes first meeting Maynard Keynes during this period, although not working closely with him. See Reminiscences, supra note 22, at 13.

74. See John Maynard Keynes, The Economic Consequences of the Peace (1919).

75. See Adolf A. Berle, NeW Directions IN THE NeW World (1940).

76. See Joseph Alsop \& Robert Kintner, American White PAPER: THe Story of AMERICAN DIPLOMACY AND THE SECOND WORLD WAR (1940).

77. Berle Diary (Feb. 17, 1941), in NAVIGATING THE RAPIDS, supra note 20, at 358-59. But by June, events on the ground, in the form of German military strikes against more countries, led to the State Department agreeing that freezes were justified.

78. SCHWARZ, supra note 3, at 155. 
2. The Substance to Be Covered by the Economic Plan: Trade, Monetary Issues, and Development

While the key players agreed on the value of planning, it took longer to identify what they wanted to plan and longer still to arrive at an agreement on the plan. Twenty-first century commentators regularly look back to the economic changes in the international order resulting from World War II and focus on three international institutions - the International Monetary Fund, the World Bank, and the World Trade Organization (and its predecessors) - created at Bretton Woods in 1944 and in other international conferences of the period. Indeed, the planning from the very beginning of the war focused on the three overlapping sets of international economic issues associated with these organizations: monetary policy, capital for development, and trade. Plummeting international trade after the stock market crash and increased tariffs of the period cut wealth across borders. Currency manipulation and continuing challenges from efforts to return to the gold standard in many countries fueled economic unrest. Insufficient capital was available for stabilization and development, a challenge made so much greater by war. Problems in each exacerbated worries in the other two.

The text for international agreements had only been completed for the IMF and World Bank when the delegates gathered at Bretton Woods in New Hampshire in the summer of 1944, but Roosevelt's message to the delegates was clear as to the integral role of trade in the overall approach to international economic relations. He noted that the program to be discussed at Bretton Woods

concerns the basis on which [ordinary men and women] will be able to exchange with one another the natural riches of the earth and the products of their own industry and ingenuity. Commerce is the life blood of a free society. We must see to it that the arteries which carry that blood stream are not clogged again, as they have been in the past, by artificial barriers created through senseless economic rivalries. ${ }^{79}$

The post-war path of the trade portion of this agenda is beyond the scope of this Article except to say that that path illustrates the interconnectedness of the various parts of international economic law that the Berle-era drafters saw clearly, the enduring centrality of the questions that were the focus of the initial planning, and the continuing relevance of that period to contemporary debates. ${ }^{80}$

79. See 1 U.N. DeP'T of STATE, ProceEdingS and Documents of the U.N. Monetary AND FinANCIAL CONFERENCE (1944).

80. U.S. and U.K. diplomats picked up the trade discussions in 1945, leading to a conference in Havana in 1948 approving a treaty that would have set up the International Trade Organization (ITO). Insufficient support in Congress for American ratification in the new Cold War political climate 
Secretary of State Cordell Hull, Berle's boss, had long dreamt of structural response to the tariffs that had grown substantially in response to the Great Depression and to the disruptions of war that had undercut trade. ${ }^{81}$ American planners saw the importance of trade to produce employment at home and how opening trade for undeveloped countries could increase the standard of living around the globe. Trade traditionally held out the lure of comparative advantage. One country (or producer) could focus more on products in which it had a relative advantage (e.g., natural resources available to it, more than to other producers) and could trade those products for other products which were not as available within its borders, but more so in some other country. Tariffs could distort this exchange as countries sought to protect their domestic producers and gain a greater share of market exchanges. This, in turn, caused countervailing tariffs and other acts by other countries and the decline of international trade.

International trade, even with no tariffs, is unlikely to leave any country with an exact match of its exports and imports, such that there will be a need for an adjustment mechanism for the currency received in exchange of the goods. The gold standard provided a long-used, if imperfect, mechanism for such adjustments. The national currency of a country that regularly imported more than it exported may well see the value of its currency (relative to gold) become less valuable and take steps to bring its imports and exports back into line. But such change in the exchange rate could lead to inflation or deflation of the country's currency that would impact the health of the domestic economy in ways that the government may wish to encourage or avoid. Thus, there would be a temptation for a country to manipulate the exchange rate, for example to make its goods cheaper and the goods from other countries more expensive. German, Japanese, and even British currency manipulation during the 1930s illustrated such distortions to the economic status quo. ${ }^{82}$ Our own times provide current examples of fears of currency manipulation and imbalances in trade and efforts and a need for international agreements to prevent crises that have led to currency wars in the past. The gold standard had another disadvantageous effect in that the natural scarcity of

blocked the ITO leading to a more informal operation under the General Agreement on Tariffs and Trade (GATT). This international cooperation grew and became more formal and very successful over time leading eventually to multilateral acceptance via treaty of the World Trade Organization in the 1990s. Disruption of the previous seven decades of international trade policy via Brexit and Trump is the reality of the current world. See generally DOUglas A. IRwIN, Clashing Over COMMERCE, A History OF US TRADE POLICY, pt. 3 (2017).

81. Richard GARDNER, STERLING DOLlar DiplomaCy 101 (1969).

82. Ed CONWAY, THE SUMMIT: BRETTON WOODS 1944: J.M. KEYNES AND THE RESHAPING OF THE GLOBAL ECONOMY 83 (2015). 
the mineral and its somewhat random distribution about the globe made it difficult for governments to quickly provide the liquidity necessary in periodic panics that gripped economies. ${ }^{83}$

Finally, the destruction of war across the globe greatly exacerbated the capital needs generated by years of economic depression. The likelihood of private capital sufficient to meet such needs seemed remote; the ability of many individual countries to generate sufficient capital internally called for an international response.

Planners seeking to put the post-war economy on firmer footing, particularly in the United States and the United Kingdom, saw all three of these challenges - trade, monetary and capital for redevelopment-as requiring an international structure beyond that which then existed. As the planning process evolved, initial attention was given first to the monetary challenge with separate plans being developed each by American and British teams. The capital needs of reconstruction were coupled with these negotiations, often as a junior partner until the second week of Bretton Woods when discussion about the World Bank took center stage. ${ }^{84}$ Trade negotiations ended up on a different track, taking somewhat longer to complete. That description, however, blurs a much more nuanced development that merits additional attention, both for what it tells us about Adolf Berle, and for better understanding where we are today on these same questions.

\section{A Rumble Along Pennsylvania Avenue: Competition Among Agencies of the American Government in Responding to Post-War Planning}

Richard Gardner in his classic book on the period, Sterling Dollar Diplomacy, observes that, "by the time the United States entered the Second World War, its great executive departments were engaged in a major struggle over their respective responsibilities for the planning of post-war foreign economic policy." ${ }^{, 55}$ The topic naturally linked to both foreign affairs and financial policy so both State and Treasury could claim a natural interest. Roosevelt was known to not rely on fixed lines of authority and preferred to let his advisers and agencies fight it out, as in

83. See Mervyn King, The End of Alchemy: Money, Banking and the Future of the GLOBAL ECONOMY 162 (2017) (discussing the importance of central bank responsibility of two key aspects of the management of money in a capitalistic economy: "to ensure that in good times the amount of money grows at a sufficient rate to maintain broad stability in the value of money" and "to ensure that in bad times the amount of money grows at a rate sufficient to provide the liquidity ... required to meet unpredictable swings in the demand for it by the private sector. . . These two functions are rather simple to state, if hard to carry out.").

84. CONWAY, supra note 82, at 237.

85. GARDNER, supra note 81 , at $71-72$. 
the drafting of the federal securities act described above. The early planning for a post-war economic structure followed a similar path of shared effort. Roosevelt wanted both State and Treasury involved and also the Board of Economic Warfare, which at the relevant time was run by Vice President Henry Wallace, a possible candidate to be Roosevelt's successor. ${ }^{86}$

State and Treasury, the bigger institutional and political players, were situated along Pennsylvania Avenue on either side of the White House. ${ }^{87}$ Hull occupied the senior cabinet seat and had a political role to match, based on his previous time in the Senate and House and his regular mention as a possible successor to Roosevelt. At Treasury, Henry Morgenthau had the advantages of more detailed knowledge of financial matters and closer personal ties to the President as his neighbor along the Hudson River. The State Department, with its traditional dominance in foreign affairs, probably should have been considered the favorite in betting on how this competition might come out, and the topic seemed a natural fit for Adolf Berle to have a major role within the Department. Schwarz described Berle as "probably the highest ranking official in Washington conversant with Keynes' ideas in 1938." 88 Berle's proposals for the government's response to the economic crisis of the late 1930s were influenced by and consistent with the stimulus favored by Keynes in times of economic weakness. ${ }^{89}$ Berle repeatedly wrote about the need for capital and new ways government might provide it. ${ }^{90}$

Like Keynes, Berle was a public intellectual of the day, comfortable in writing and speaking about a variety of topics. This period also showed Berle's ability to present a broader message of America's changing role in the world economy, a topic on which Berle was optimistic. In a Fortune magazine piece before Pearl Harbor, he forecast that the United States would emerge from the war as the richest country and with an altruistic policy, because - in the natural order of things — any economics is moral. ${ }^{91}$

86. This agency went through various name changes and reorganizations of its own in the period before and after the United States joined the war. The Economic Defense Board, chaired by the Vice President, was established in the summer of 1941 while the United States was still ostensibly neutral. After Pearl Harbor, the name changed to the Board of Economic Warfare, although recommendations to the President from both the Board and the State Department would be made through the office of the Secretary of State. Harley A. Notter, U.S. DeP'T of State, No. 3580, Postwar Foreign POLICY PREPARATION 1939-1945 (1949).

87. State was then located in the building currently known as the Eisenhower Executive Office Building, adjacent to the West Wing of the White House.

88. See SCHWARZ, supra note 3, at 119.

89. See CONWAY, supra note 82, at 90 and accompanying text.

90. See SCHWARZ, supra note 3, and accompanying text.

91. Adolf A. Berle, And What Shall We Do Then, ForTune, Oct. 1941, at 124. 
In a speech before the Yale Political Union the previous year, he presciently observed that it may seem

fantastic today to suggest handing over some of our accumulated gold as a free gift to re-establish international currency, to let other nations set their house in order, and thereby reestablish trade and normal life. But this may not seem so fantastic a few years hence. It seems impossible today to think of using the enormous resources of the Federal Reserve System as a means of rebuilding the shattered life of another continent, but when the time actually comes ... we may find the idea looks more like an immediate necessity than a fairy tale. ${ }^{92}$

The actual outcome, in which Treasury, not State, ended up with the major role and Berle was eclipsed, not just in dealings with the British, but also within State, is a revealing part of the Berle story.

4. The Evolution of Post-War Planning in Three Acts: During American Neutrality; the Rumble Along Pennsylvania Avenue; and Treasury Triumphant

\section{a. During American Neutrality Before Pearl Harbor}

Planning for the post-war period began almost as soon as Germany invaded Poland in 1939. Two weeks later, Hull appointed Leon Pavolsky as special assistant to work on the problems of peace. ${ }^{93}$ By the end of the year, Hull had appointed a ten-member committee on the Problems of Peace and Reconstruction that included most of the senior officers on duty, including Pavolsky and Berle. ${ }^{94}$ In another two weeks, the title morphed into the Advisory Committee on Problems of Foreign Relations to work through three subcommittees: politics, armaments (soon folded into politics), and economics. Berle served on the economics subcommittee, which was the first to organize, and focused on a conference of neutrals. ${ }^{95}$

In May, after large German gains across western and northern Europe, a new interdepartmental committee was created-the Interdepartmental Group to Consider Post-War International Economic Problems and Policies. The State Department numerically dominated this group, but its membership went outside the State Department to bring in

92. Eden Statement Issued in Capital, N.Y. TiMES, Sept. 25, 1941, at 4 (quoting Berle's speech on post-war adjustments in 1940 before the Yale Political Union); see Leo E. Strine, Jr., Made for This Moment: The Enduring Relevance of Adolf Berle's Belief in a Global New Deal, 42 SEATTLE U. L. REV. 267 (2019) (describing Berle's role in presenting an optimistic message of America's place in the world in this period).

93. NOTTER, supra note 86 , at $17-19$.

94. Id. at 20.

95. Id. at 22 . 
officials from Treasury, Commerce, and Agriculture. ${ }^{96}$ This group included Treasury Secretary Henry Morgenthau and his Chief Advisor on Monetary Policy Harry Dexter White, who would play a large role as the Bretton Woods process unfolded. The last seven meetings of this group in the last quarter of 1940 were devoted wholly to post-war preparations. ${ }^{97}$

During this period, Berle worked with Harry Dexter White on an inter-American bank to finance development in Latin America, in part as a means to withstand totalitarianism in the western hemisphere. As Berle biographer Jordan Schwarz described it, Berle's idea was based on "little more than a casual conversation" with Jesse Jones at the RFC and faced resistance from Treasury Secretary Morgenthau, but White's "first-class missionary work" at Treasury and Jones's efforts with bankers got the backing of the President. ${ }^{98}$ Congressional resistance to funding and the failure of several countries to subscribe their shares eventually put this proposal on the shelf. Nevertheless, White and his Treasury team, in the first half of 1942, developed a Stabilization Fund and Development Bank proposal for a global response which, along with Keynes's proposal for a clearing union, became the fulcrum of discussion from that time through the Bretton Woods conference in 1944, as discussed in the next section. ${ }^{99}$

Anglo-American discussions in the period prior to Pearl Harbor about Lend-Lease, the American provision of key armaments and supplies to the United Kingdom and other countries without immediate payment, raised the curtain on what would be the most contested issues of post-war economic planning. In preparing for talks to be held in Washington during the summer of 1941, the State Department was attuned to Hull's interest in trade and the rising tide of American dominance in international exchange; they wanted to see trade free of discrimination in favor of British colonies as part of the tradeoff for Lend-Lease. Keynes, making his first trip to Washington on behalf of the Treasury, pushed back on such ideas arguing that the post-war recovery of the U.K.'s economy sufficient to repay the loans taken out to fund the heavy costs of fighting Germany would require discrimination in favor of future trade between London and its colonies. This issue became a key topic of discussion at the Atlantic Conference between Churchill and Roosevelt in Newfoundland in August 1941. Welles, in reaction to Keynes's earlier statements in Washington, pushed for a strong prohibition of discrimination in trade. Churchill balked. Roosevelt suggested language papering over the divergent views

96. SCHWARZ, supra note 3, at 131. 97. NOTTER, supra note 86 , at 38 . 98. SCHWARZ, supra note 3 , at 131. 99. GARDNER, supra note 81 , at 74 . 
with the precise meaning to be worked out in later discussions, which would extend well past the end of the war. ${ }^{100}$

\section{b. After Pearl Harbor}

In 1942 with America now at war, interdepartmental planning for post-war efforts stepped up again and became more detailed. An Advisory Committee of officials at State and other Departments and members of Congress was formed and organized into six subcommittees that met weekly. Berle was active in the economic subcommittees of this group, chairing sixteen meetings in the first half of 1942 with Dean Acheson, at this point also an Assistant Secretary of State, chairing other meetings. ${ }^{101}$

Monetary and banking strategizing was typically a concurrent activity under the leadership of Treasury. Here is where the most important preparatory work for Bretton Woods actually occurred. Keynes, after the Lend-Lease brouhaha, had begun drafting a new plan for monetary policy based on a sophisticated concept of a "Clearing Union" which would permit countries to trade "bancor" units. This new currency unit, as an alternative to gold, would provide more flexibility than a gold standard to debtor nations (as the United Kingdom had become, with the necessity of war borrowings). After Pearl Harbor, Treasury Secretary Morgenthau put White in charge of Treasury's foreign relations and asked him to "provide [a] basis for [a] postwar international monetary arrangement." 102 White proceeded to develop his own stabilization and development plan more reflective of the United States position as a creditor nation and the rising hegemon in international financial affairs. The Keynes and White plans formed the basis for U.S.-U.K. discussions culminating with the agreements at Bretton Woods.

In July 1942, one of the interdepartmental planning committeesthis one chaired by White-decided on bilateral discussions of memoranda (i.e., the Keynes and White proposals) with the British as the way forward; these conversations occurred in September. While Berle had pushed for discussion of the White plan at the July meeting, in between that meeting and the bilateral discussions, he promoted his own proposal

100. Id. at 41-42, 46-47. Churchill relied on a statement by Roosevelt in Newfoundland that the U.K. was no more committed to the abolition of Imperial Preferences than the American government was to its high protective tariffs. In speaking to the House of Commons, Churchill suggested this left the British "perfectly free" in terms of actions it could take. Whatever the ambiguity of the language, economic realities of the war and immediate post-war years left the U.K. with much less room for action than Churchill's words might have suggested. See ED CONWAY, Starvation Corner, in THE Summit: BRetton WoOds 1944: J.M. Keynes AND the Reshaping OF the Global ECONOMY, supra note 82 , ch. 4 .

101. See NOTTER, supra note 86, at 79-92.

102. DAVID ReES, HARry DeXter White: A StUdy IN PARADOX 137 (1973). 
for a United Nations Bank for economic reconstruction. ${ }^{103}$ When Keynes came to Washington to discuss these plans in September of 1942, the first meeting was in Berle's office ${ }^{104}$ and Berle continued to be the point person at State in the months that followed. Assistant Secretary of State Dean Acheson had told the British representative that financial matters were under Berle. ${ }^{105}$ The American questions to the U.K. about the Keynes plan went through Berle in October and came back to Berle in November. ${ }^{106}$ In between, Berle gave a major speech on foreign policy on October $15 .{ }^{107} \mathrm{In}$ late 1942, it seemed to the British and the Canadians that Berle was calling the shots "for the financial aspects of post-war planning.".

\section{c. Treasury Triumphant}

Behind the scenes things were shifting. In October, Morgenthau and White went to England ostensibly to discuss finances for the invasion of North Africa. But the Americans arranged for White and Keynes to meet for a long substantive session of the two monetary plans. ${ }^{109}$ After the State Department's formal notification in November that it was ready to proceed with talks on monetary policy between the U.S. and U.K. governments, the White and Keynes plans picked up their earlier discussions. In the first part of 1943 as differences still remained, Berle agreed to continue bilateral conversations but did not want it to appear as if other nations were being presented with a fait accompli. Thus, Berle initiated discussions with the Chinese. ${ }^{110}$ Over the next two months the U.S. and U.K. camps bickered back and forth as to whether the two competing plans would be published and if so, by whom, leading to eventual leaks and publications of both. As the plans had become more detailed and more public, the role of Treasury had become more entrenched. By early spring, clarity came in the form of an official U.S. announcement that Treasury "though consulting with others, would be expected to "carry the ball."" 111 In the

103. BERLE, supra note 20, at 418-19.

104. ARMAND VAN DORMAEL, BRETTON WOODS: BirTh OF A MONETARY SYSTEM 59 (1978).

105. Id. at 56-57.

106. Id. at 60 .

107. GARDNER, supra note 81 , at 166.

108. SCHWARZ, supra note 3, at 213-14. This did not mean, even in September 1942, that the White and Keynes plans were not the basis for the conversation, as Berle himself acknowledged in the meeting in his office on September 10. Id. at 214.

109. CONWAY, supra note 82, at 135.

110. SCHWARZ, supra note 3, at 214.

111. VAN DORMAEL, supra note 104, at 83. "After struggling for a full year to wrest from the State Department the authority and responsibility for international postwar monetary planning, Morgenthau and White had won." Id. at 81. 
future, the British would go to Morgenthau, not Berle. ${ }^{112}$ When Keynes again visited Washington in September of 1943, Berle sat in on the meeting but deferred to Treasury leadership. ${ }^{13}$ When the two countries and allied nations met the following July in Bretton Woods for the conferences proposing the IMF and the World Bank, Berle did not attend.

The State Department retained the lead role in negotiations for trade (labeled by the two sides as "commercial"), but Berle was not a leading figure in that either. The September 1943 meetings involved a combined British delegation that came to Washington for both trade and monetary discussions. Berle was involved but not like the previous year. The WhiteKeynes talks continued at long-distance through the fall, winter, and spring, at Atlantic City in the week before the beginning of the Bretton Woods conference and then for most of the month of July at Bretton Woods.

When the President called on Congress to pass the Bretton Woods proposals for the IMF and the World Bank, he noted his expectation that proposals for the reduction of trade barriers and other matters "will shortly be ready to submit to you for your consideration" as part of the United States taking the lead in "establishing the principle of economic cooperation as the foundation for expanded world trade." 114 Yet, the trade part had not made nearly as much progress as the monetary portion. While the monetary issues had been assigned to Treasury in the spring of 1943, trade remained under the State Department, with a delegation led by Myron Taylor, Harry Hawkins, and Dean Acheson-not Berle. Those talks got no further than broad agreement on the importance of trade to expand employment and to identify the issues of quantitative restrictions and trade preferences but put off the next steps until the beginning of 1945 . In December of 1945 the United States invited the wartime allies to enter into negotiations for a multilateral agreement on trade in goods with related talks in London and Geneva leading to a charter of an International Trade Organization approved in Havana in March 1948. ${ }^{115}$

\section{d. Denouement}

As these broader international economic issues moved away from Berle during the war, one area remained, that of a proposed international

112. Letter from Sir Frederick Phillips (the U.K. Treasury's permanent representative in Washington) to J.M. Keynes (Apr. 22, 1943), in VAN DORMAEL, supra note 104, at 81.

113. SCHWARZ, supra note 3, at 215.

114. Franklin D. Roosevelt, Message to Congress on the Bretton Woods Agreements (Feb. 12, 1945).

115. But the U.S. Congress failed to ratify the treaty and international trade relations were left to the more informal process under the GATT. See IRWIN, supra note 80, at 473-83, 500-01. 
civil aviation treaty with the conference to be held in November of 1944 in Chicago. Differences between the U.S. and the U.K. over rights to fly the Atlantic held up a final agreement, although eventually there was a treaty and an international civil aeronautics association that reflected Berle's work. During the conference held shortly after Roosevelt's reelection, White House advisor Harry Hopkins flew out to Chicago to tell Berle there was not a place for him in the fourth term. ${ }^{116}$ Sumner Welles left as Undersecretary the previous year and Hull was retiring at the end of the month. The new Secretary would bring his own people.

The position offered to Berle was Ambassador to Brazil, which he did for thirteen months with mixed results. ${ }^{117} \mathrm{He}$ negotiated to be able to attend a conference in Mexico City in early 1945 and to make a personal report to the President. But by April, the President was dead and Berle soon headed back to New York and Columbia.

\section{Responsibility Outside of Economic Planning}

While Berle had his largest continuing impact on various matters relating to economics, there were other topics of recurring responsibility. Latin America, a life-long interest discussed elsewhere in this Article, was one, intelligence was another. Berle's government service first intersected with intelligence in World War I during his time in the Dominican Republic. After completing his work relating to land titles affecting sugar, he extended his stay at the request of the governor and the chief of military intelligence to feel the pulse of the countryside. ${ }^{118}$ When the State Department set up an intelligence division in late 1940, Roosevelt soon asked that Berle coordinate overlap with the FBI and its director, J. Edgar Hoover. ${ }^{119}$ The FBI already operated outside of the U.S. in Latin America and, in consultation with Berle and military intelligence, decided to create a Special Intelligence Service to operate in South America. When the U.S. later decided to set up a separate secret intelligence agency the President first followed his "competition between agencies" approach with Berle negotiating for the FBI to have the western hemisphere and military intelligence with responsibility for the rest of the world. As William Donovan's Office of Strategic Services grew, Berle's role diminished.

Berle's role in the State Department intelligence led to his involvement in two other intelligence matters that subsequently gained political prominence: Whittaker Chambers' 1939 charges that Alger Hiss

116. SCHWARZ, supra note 3, at 248.

117. Id. at 254-79 (describing a Berle speech in September that set off a storm of controversy). 118. $I d$. at 21 .

119. For a discussion of Berle's assignments regarding intelligence discussed in this paragraph, see generally $i d$. at $171-72$. 
was a communist agent, leading to two trials and Hiss's conviction of perjury in 1950; and similar charges against the Treasury's Harry Dexter White that led to Berle's statement to another Congressional committee later in the 1950s. In 1939, Chambers had gone to the White House to expose Alger Hiss, then a State Department employee, as a communist. ${ }^{120}$ Marvin MacIntyre, the President's secretary, told Chambers to take it to Berle in the State Department overseeing intelligence. The day after Germany invaded Poland, Chambers revealed his charges to Berle, who took notes and reported it to the President. FDR showed little interest in the report, nor did others seem interested in pushing it along. Germany was the focus - the Soviet Union had by that time signed a non-aggression treaty with Germany, eventually becoming an American ally after Germany's invasion the following year. Eighteen months after the Chambers visit, Berle went to the FBI in March 1941 and asked what it knew of Chambers. Fourteen months went by before the FBI interviewed Chambers and an additional thirteen more months went by before the Bureau requested Berle's memo of 1939. More time passed until the State Department's security office questioned Chambers in March 1945. Elizabeth Bentley, another self-confessed Communist spy, went to the FBI with her own allegations about Hiss in 1945, but there was still little immediate movement. ${ }^{121}$

Once the 1946 elections switched control of the House of Representatives, and in the face of rising tensions between the United States and the Soviet Union, the activity relating to the old accusations picked up. The House Un-American Activities Committee (HUAC) held hearings in 1948 including Chambers's charges against Hiss, who had risen in the State Department in the nine years since Chambers-Berle meeting, eventually serving as a presidential advisor at Yalta and helping set up the United Nations. ${ }^{122}$ Hiss's strong defense to the charges and his libel suit against Chambers provoked Chambers to produce additional evidence and that provided part of the basis for perjury charges against Hiss. When called to testify before the HUAC committee, Berle downplayed the importance of Russian surveillance as an existential threat and took a swipe at Dean Acheson, then undersecretary, for the

120. The chronology in this paragraph reflects SCHWARZ, supra note 3, at 299. See also BENN Steil, The Battle of Bretton WoOds: John Maynard Keynes, Harry DeXter White and the MAKING OF A NEW WORLD ORDER 293 (2013) (noting the FBI waited more than a year before requesting Berle's 1939 memo).

121. STEIL, supra note 120, at 293-95.

122. Hiss was then head of the Carnegie Institute for International Peace. For a discussion of the HUAC hearings relevant to Chambers and Berle, see generally SCHWARZ, supra note 3, at 300. 
Department's failure to pursue Berle's preferred hard line toward the Russians. ${ }^{123}$

A second parallel thread of Congressional hearings into alleged communist spying involved charges made against Harry Dexter White. ${ }^{124}$ White had been nominated by President Truman in January, 1946, to be the American executive director of the IMF, with the expectation that the United States would back him for managing director, the top position of the new entity. ${ }^{125}$ However, White's name had surfaced in allegations by Elizabeth Bentley who had named White as part of a group in Treasury and other departments who were funneling information to Russia. ${ }^{126}$ In late 1945, J. Edgar Hoover had informed the White House's FBI liaison, with copies to the Secretary of State and Attorney General, warning of the danger of appointing White to the IMF, but that information did not seem to have any effect before White's nomination was announced. Hoover then prepared a special report for the President that set off alarm bells at the White House; yet even here the keystone cops caper continued as the White House's call to the Senate to stop the vote on the nomination came too late. ${ }^{127}$ To avoid signaling American knowledge of the spy ring, the Administration chose to not seek White's resignation or removal. However, the Administration did choose not to put White's name forward for the top IMF job, saying it would support an American instead for the top job at the World Bank. ${ }^{128}$

Even so, White only stayed one month past the March 1, 1947 official opening of the IMF doors. He was interviewed by the FBI in August 1947, had a severe heart attack soon after, and testified before a grand jury March 24 and 25, 1948, but was not indicted. After Chambers and Bentley both testified before HUAC that summer against White, White himself testified on August 13, gaining positive reports in the press. ${ }^{129}$ On the train to his summer home in New Hampshire the next day he suffered a second severe heart attack and died the following day. Congressional attacks on White continued posthumously with Richard

123. SCHWARZ, supra note 3, at 300-01. Berle, in testimony that seemed to fit more in the category of settling old scores than about the matter at hand, said that his opposition to Acheson's approach in 1944 led to his going to Brazil "and that ended my diplomatic career." Id.

124. See generally R. Bruce Craig, Treasonable DoubT: The Harry DeXter White Spy CASE (2004). See also CONWAY, supra note 82, at 334-64.

125. For a chronology of the hearings and related activities discussed in this and the following paragraph, see STEIL, supra note 120, at 291-324.

126. Id. at 295 .

127. Id. at 298-99.

128. Thus, the pattern of an American to head the World Bank and a non-American to head the IMF, still followed today, is the opposite of what was expected at the time and resulted from the happenstance of the timeline of revelation of the information about White. Id. at 299-300.

129. Id. at 319-22. 
Nixon revealing in 1950 that he had documents hand-written by White that had been turned over by Chambers, from the same hidden cache of "Pumpkin Papers" that had surfaced during the Hiss investigation. In 1951 both Bentley and Chambers testified against the deceased White before a Senate committee. ${ }^{130}$ Two years later, counsel for another Senate committee called on Berle looking for testimony on whether Harry Dexter White was a Russian spy. Berle replied that he had no knowledge of the now deceased White and did not much care. "There were Soviet spies and there was Communist infiltration. Taken together, it made a little trouble and probably did not vary greatly the course of affairs. ... But directing the whole course of American politics in 1954 to examination of the mistakes of 1944 gets us absolutely nowhere." 131

\section{Post-WAR ReTURn to NeW York CITY AS A PUBliC INTELlECTUAL, PROFESSOR, AND POLITICIAN}

After a rocky thirteen months in Brazil, Berle returned to New York to teach, practice law, participate in state and national politics, and contribute to the public discussion of ideas. With Truman now President, Berle no longer enjoyed the access to the White House that he had for twelve years. The Liberal Party of New York became his platform for political involvement when he became chair in early 1947. The party enjoyed some success in pursuing a balance-of-power strategy; for example, it helped Herbert Lehman beat John Foster Dulles in the Senate race in 1949. Berle retained some personal influence, serving as part of Stevenson's brain trust in 1952 and 1956 and interacting with the Eisenhower Administration via Nelson Rockefeller (then a top official at State), Allen Dulles at the CIA, and others. He joined a group with roots back to the Versailles peace conference to help found Radio Free Europe and volunteered more than half of his time to that cause in the early 1950s. In some ways the pattern parallels his political involvement in New York between 1933 and 1937-with one difference: The third party balance of power strategy did not provide any significant key policy-making influence once the election was over in contrast to what had happened in the LaGuardia Administrations.

Latin America provided a continuing, if still sporadic, entre to policy-making in an area Berle cared about. In the early part of the Eisenhower Administration, he journeyed to Costa Rica for discussions with its President and was involved in addressing its conflict with

130. Id. at 293-99, 318-24.

131. See SCHWARZ, supra note 3, at 303 (quoting Letter from Adolf A. Berle to Alice Berle, his daughter (Nov. 23, 1954) (on file with the Franklin D. Roosevelt Presidential Library, Berle Papers, Box 82). 
Nicaragua, its larger neighbor. At the later request of the CIA he helped the elected President of Honduras deal with a military coup. Later in the decade, he continued to be involved as Latin America responded to the Cuban revolution. More generally, he collaborated with Henry Kissinger in a years-long task of a Rockefeller Fund report chaired by Dean Rusk, putting him in the orbit of two future Secretaries of State. ${ }^{132}$ When John Kennedy was elected President in 1960, Berle wanted in. He was asked to chair a transition task force on Latin America, leading to a position as chair of an interdepartmental task force on Latin America with an office in the State Department near Rusk (who had said that all roads in Latin American affairs led to Berle). ${ }^{133}$ This was a task an intellectual jobber could appreciate, and he signed on for six months. Unfortunately for Berle, the Bay of Pigs invasion of Cuba, a CIA operation, dominated the history of those six months that some in Latin America saw as unilateral intervention, and one which the anti-Castro Cubans saw as Americans leaving them on the beaches. With the failure of the mission and the Administration's Latin American policy in some disarray, Berle returned to New York.

Berle had at least one more role on the national political stage. When Lyndon Johnson became President after John Kennedy's assassination, New Dealers like Abe Fortas and Jim Rowe were close to the new President and reached out to Berle to provide an FDR connection for LBJ. ${ }^{134}$ Berle became involved in the Dominican Republic, where his interest in foreign policy had been sparked a half century before. Berle sought to walk the line between differing factions, but in late April 1965 Johnson ordered a United States invasion, which Berle, the long-ago advocate of Dominican self-determination, justified to prevent a Castromounted takeover. The following month, Johnson invited Berle to lunch at the White House. ${ }^{135}$ The President also wanted to discuss an even bigger topic, Vietnam, and here too, Berle seemed willing to have the United States fight to keep freed colonial people free from communism.

Against this pattern of somewhat humbling results in politics and diplomacy over the second-half of his career, Berle found a continuing outlet in his academic and policy writing. Upon rejoining Columbia, he returned to law review writing (which he had abandoned, except for a couple of exceptions after 1934) and authored a dozen books. Even more,

132. For a discussion of Berle's involvement in Latin America issues in the 1950s, see generally SCHWARZ, supra note 3 , at 311 .

133. Id. at 327-28.

134. For a discussion of Berle's political activities during the Johnson Administration, see generally SCHWARZ, supra note 3, at 344-51.

135. Berle Diary (May 28, 1965), in NAVIGATING THE RAPIDS, supra note 20 ("To enter history again, however modestly, is I suppose a compliment."). 
his biographer Schwarz noted, "Perhaps nothing else during these troubled times gave Berle more satisfaction than his chairmanship of the Board of Trustees of the Twentieth Century Fund. He saw in the Fund his last great quest to be a powerful brain truster - a 'causative' intellectual making history." 136 That public policy think tank permitted him to explore, and support others in exploring, a variety of issues across a broad range of topics.

Berle's most lasting impact in the post-1932 period was his own academic writings. His post-1946 law review articles took some of his earlier topics and developed them in light of developments since 1932. His 1952 Pennsylvania Law Review article, Constitutional Limitations on Corporate Activity, may be the most creative of this group. Anticipating the constitutional debate of the early twenty-first century on constitutional rights of corporations, Berle started from the then-current picture of corporate law: "classic corporation law is almost never availed of to adjust the relations between the corporate enterprise and the community." ${ }^{137}$ For the 1932 Berle, this was a no-brainer: corporations have economic and political obligations and privileges and are expected to produce an economic result acceptable to the community. The 1952 article saw the challenges in extending individual rights, but not in the way that contemporary cases like Citizens United ${ }^{138}$ and Hobby Lobby ${ }^{139}$ have developed. Berle's focus was more on corporations being subject to the constitutional limitations which limit the state itself because of the power that has accrued to those entities. ${ }^{140}$

Elsewhere, Berle dealt with a disconnect between corporate theorythe sovereign's grant of certain attributes of personality to a corporate group - and the underlying economic reality of an enterprise operating via multiple entities within an enterprise. ${ }^{141}$ Berle put forward a revision of the classic conception, arguing for enterprise liability. A principal focus was the then-recent liability-creating Supreme Court case Anderson v. Abbott, written by his former Columbia colleague and fellow-New Deal progressive, William O. Douglas. ${ }^{142}$ In another article, he took on the

136. SCHWARZ, supra note 3 , at 351.

137. Adolf A. Berle, Jr., Constitutional Limitations on Corporate Activity-Protection of Personal Rights from Invasion Through Economic Power, 100 U. PA. L. REV. 933, 936 (1952).

138. Citizens United v. Fed. Election Comm'n, 558 U.S. 310 (2010).

139. Burwell v. Hobby Lobby Stores, Inc., 134 S. Ct. 2751 (2014).

140. Berle, Constitutional Limits, supra note 137.

141. Adolf A. Berle. Jr., The Theory of Enterprise Liability, 47 COLUM. L. REV. 343 (1947).

142. Anderson v. Abbot, 321 U.S. 349, 363 (1944) (applying the statutory double liability of bank shareholders for the bank liabilities to extend to the individual shareholders of the parent corporation owning the majority shares of the bank despite the normal effect of corporate existence to act as an insulator from liability: "To allow this holding company device to succeed would be to put the policy of double liability at the mercy of corporation finance.”). Four justices dissented, arguing 
question of corporate control, as in the then-recent case of Perlman $v$. Feldmann, written by another strong New Dealer on the Second Circuit, Charles Clark. ${ }^{143}$ A core foundation of this article, common to his other writing, was the community's "vivid interest in the policies and operations of the corporation." 144

In Berle's last article, he returned to a theme of The Modern Corporation and Private Property to emphasize the change in the nature of property resulting from the rise of the corporation. ${ }^{145}$ Unlike his first employer, Brandeis, he had long before cast his lot with accepting the large corporation and using government to match it. In the Constitutional piece discussed above, Berle outlined the direction law should follow "to assure that the market power of the enterprise shall not be used so as to create or perpetuate conditions that the state itself is forbidden to create or maintain." 146 In Property, Production and Revolution, he suggested the need for a new role for shareholders with a different kind of governance role reflecting a more transitory ownership of stock in large corporations that was essentially more liquid than comparable interests in earlier businesses. Shareholders in this view act less as an allocator of capital and more as a "vehicle for rationalized wealth distribution corresponding to and serving the American ideal of a just civilization." 147 In these ideas, Berle came closest to a reprise of the ideas of his intellectual trifecta of 1932.

\section{CONCLUSION}

Eighty-five years after his most notable intellectual contributions, Adolf Berle's impact still can be characterized as distinctive. His public renown has been surpassed by few law professors before or since. What explains his lasting recognition? Ideas, like people, come in a multitude of variations. In one sense, his recognition reflects a particular idea at a

that Congress had not "announced a legislative policy such as the Court announces." Id. at 374 . Berle was sympathetic to some broadened liability across entity boundaries but would permit a corporate group to preserve separateness if the parent required the subsidiary to "manage its own affairs, make its own decisions, and operate as a separate entity." Berle, Enterprise Liability, supra note 141, at 357.

143. Perlman v. Feldmann, 219 F.2d 173 (2d Cir. 1955) (controlling shareholder breached fiduciary duty by siphoning off for personal gain corporate advantages to be derived from a favorable market situation due to quasi-price controls during the Korean War, but not saying that a majority shareholder can never dispose of controlling block for a premium).

144. Adolf A. Berle, Jr., "Control” in Corporate Law, 58 Colum L. REV. 1212, 1215 (1958). Berle argued that Perlman went far in the direction of his position in MCPP - that control belongs to the corporation, not the shareholders who can deliver control, and that those who run corporations are stewards for employees, customers, suppliers, and the community affected by their operations. Id. at $1212,1221$.

145. Adolf A. Berle, Jr., Property, Production and Revolution, 65 CoLuM. L. REV. 1 (1965).

146. Id. at 10 .

147. $I d$. at 17 . 
particular time. There was a new kind of a corporation in a changed economic setting that required a different government response. How many professorial efforts could be fit into such a template? The difference was the timing. The severity of the Great Depression and then the world war that accelerated the coming of an American hegemon in global economics enhanced and deepened the questions he addressed and magnified the usefulness of the framework he identified. In the absence of those factors it is not surprising that he could not replicate the impact of his 1932 ideas as part of the Roosevelt Administration over the next twelve years or as a public intellectual in the quarter-century that followed. The match in those times of ideas and current political trends were more ordinary. Yet a deeper understanding of both what fit so well in the early 1930s and less so afterwards can productively inform our analysis of current challenges. Berle demonstrated that a law professor skilled in the nuances of corporate law could simultaneously be a force in broader policy matters with an effect lasting generations. 